\title{
PAPAVERETUM FOR ANAESTHESIA AND ITS COMPARISON WITH MORPHINE. ANAESTHETIC TIME/DOSE CURVES VIII*
}

\author{
Michaet KeEri-Szanto $\nmid$
}

Papaveretum is a standardized combination of the four principal opium alkaloids - morphine, codeine, papaverine and thebaine. It antedates all synthetic narcotics in current use and is among the handful of drugs that have stood the test of 65 years' exposure. It is considered superior to morphine by its advocates in that it provides a better degree of sedation for a given level of analgesia and has fewer gastrointestinal side-effects. An added advantage is the fact that the intravenous injection of more than 10 to $15 \mathrm{mg}$ of papaveretum will produce a transient but violent headache in most individuals. This effect, linked most likely to its papaverin content, should reduce the compound's addiction potential. Others, and they include the authors of most textbooks and drug-evaluation manuals, maintain that the added expense of the mixture is not justified because in the concentrations used, morphine is its only active ingredient. All these claims and counter-claims are based on clinical impressions or on trials consisting of pain-score determinations and recordings of the incidence of side-effects.

Since morphine is gaining in popularity as an all-purpose anaesthetic, particularly when combined with nitrous oxide and relaxants, it appeared of interest to test in a more quantitative fashion whether or not papaveretum represents an improvement over morphine in the operating room.

\section{Material and Methods}

Thirty-two patients were studied. They were unselected except for being referred to the writer for anaesthesia which was expected to exceed three hours in duration. The patients either received papaveretum 10-15 mg intramuscularly as premedication 90 minutes before start of the operation or arrived unpremedicated in the operating room. The rigidly standardized technique of induction and maintenance have been described before. ${ }^{1-3}$ Briefly it consisted of using the narcotic as the only intravenous anaesthetic in conjunction with the exhibition of 67 per cent nitrous oxide and controlled, isocapnic ${ }^{4}$ ventilation. Muscle relaxants were reserved for providing a satisfactory surgical field. A steady depth of anaesthesia, judged by minimal changes in signs, was maintained by repeated small injections of papaveretum as needed.

An anaesthetic time/dose curve ${ }^{5}$ was constructed for each patient from the size and timing of successive increments of papaveretum; from this curve the loading and maintenance fractions of the total narcotic dose were read. In patients who received premedication, this was included in the calculations.

'Department of Anaesthesia, Victoria Hospital, London, Ontario, N6A 4G5.

$¥$ Clinical Associate Professor, Department of Anaesthesia, University of Western Ontario, London, Ontario, Canada. 
The same information for morphine had been established previously in a different sample from the same hospital population ( 46 subjects) and has been published in part. ${ }^{6}$ This group serves as control for the present study.

\section{RESULTS}

Table I contains relevant data about the composition of and the operations in the two groups.

Table II presents figures about the priming and maintenance requirements in the two groups, dispersion around the mean values, coefficients of variability and the statistical significance of the observed differences. In calculating the amount of morphine present in papaveretum, allowance was made for the fact that it contains anhydrous morphine rather than the hydrated form in morphine sulfate making $20 \mathrm{mg}$ papaveretum equal $13.3 \mathrm{mg}$ morphine sulphate.

Some of the information from Table II is presented in graphical form in Figure 1.

\section{Comment}

Patients in the two groups are well matched for age, sex, anaesthetic risk and duration of anaesthesia (Table I). Matching is less satisfactory when the sites of operation are compared. We have no complete explanation to offer in this regard: a good part of it is due to the presence of relatively uncomplicated gynaecological operations and interventions on the biliary tract in the morphine series.

TABLE I

Characteristics of Patient Population

\begin{tabular}{lcc}
\hline \hline & Papaveretum & Morphine \\
\hline Age, years $\pm \sigma_{M}$ & $55 \pm 3$ & $54 \pm 3$ \\
Sex, M/F & $17 / 15$ & $23 / 23$ \\
Risk other than ASA \#1 & 8 & 9 \\
Anaesthesia time hours $\pm \sigma_{M}$ & $4.0 \pm 0.4$ & $3.8 \pm 0.4$ \\
Site of Operation: & 13 & 26 \\
$\quad$ Intraperitoneal & 13 & 12 \\
Head, Neck, Limbs & 6 & $\frac{8}{46}$ \\
Others & 32 & \\
\end{tabular}

TABLE II

Average Drug Requirements

\begin{tabular}{|c|c|c|c|c|c|c|c|}
\hline & $\begin{array}{c}\text { Loading } \\
\text { Dose } \mathrm{mg} \mathrm{kg}^{-1}\end{array}$ & $v_{\sigma}$ & $\begin{array}{c}\text { Maintenance } \\
\text { rate } \mathrm{mg} \mathrm{kg} \mathrm{kg}^{-1} \mathrm{hr}^{-1}\end{array}$ & $v_{\sigma}$ & $\mathrm{Khr}^{-1}$ & $v_{\sigma}$ & $\mathrm{t} / 2 \mathrm{hr}$ \\
\hline $\begin{array}{l}\text { Papaveretum } \\
\text { Morphine in }\end{array}$ & $0.408 \pm 0.029$ & 0.40 & $0.0744 \pm 0.0080$ & 0.53 & $0.1927 \pm 0.018$ & 0.53 & 3.6 \\
\hline $\begin{array}{l}\text { Papaveretum } \\
\text { Morphine } \\
\text { tp/m }_{\mathbf{p}}\end{array}$ & $\begin{array}{c}0.271 \pm 0.019 \\
0.330 \pm 0.018 \\
2.25 \\
<0.05\end{array}$ & $\begin{array}{l}0.40 \\
0.34\end{array}$ & $\begin{array}{c}0.0495 \pm 0.0053 \\
0.0370 \pm 0.0032 \\
2.01 \\
<0.05\end{array}$ & $\begin{array}{l}0.53 \\
0.57\end{array}$ & $\begin{array}{c}0.1927 \pm 0.018^{*} \\
0.1120 \pm 0.015 \\
3.00 \\
<0.01\end{array}$ & $\begin{array}{l}0.53 \\
0.91\end{array}$ & $\begin{array}{l}3.6 \\
6.2\end{array}$ \\
\hline
\end{tabular}

*c.f. text. 


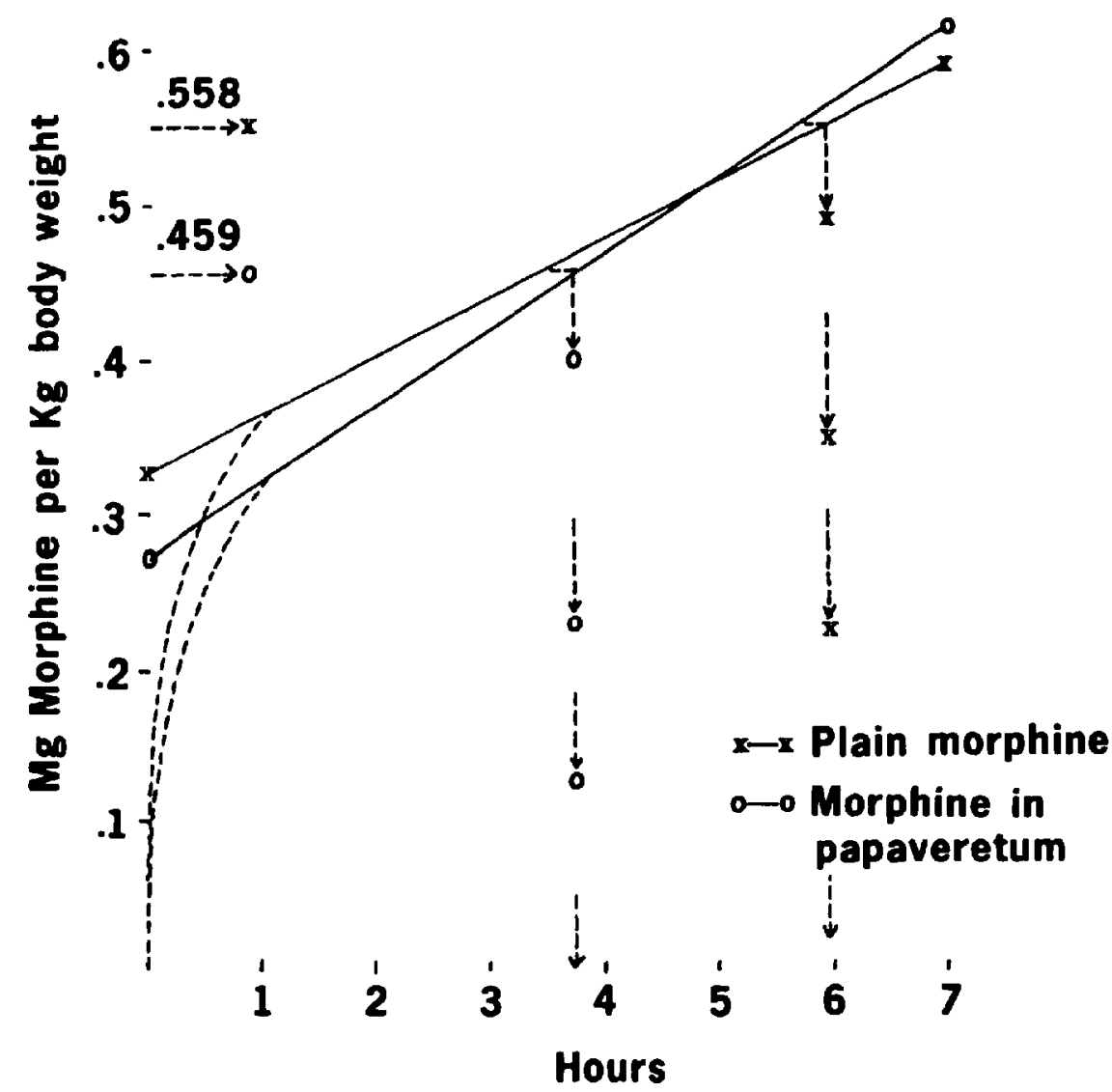

FIGURE 1. Mean anaesthetic time/dose curves of 46 subjects receiving morphine and of 32 subjects receiving Papaveretum for the supplementation of nitrous oxide relaxant anaesthesia. The therapeutic half-life of the two agents may be calculated by establishing the time co-ordinate of 1.692 times the zero intercept of the linear portion of the curve. These values and the resulting therapeutic half-lives are indicated in the graph.

Their replacement with extensive extra-abdominal operations (laryngectomy, back fusion, total hip arthroplasty, reimplantation of ureters, etc.) should not influence the average loading requirements for anaesthesia, as we have discussed earlier. ${ }^{2}$ The site of operation should influence even less the rate of metabolism of the agent or the therapeutic half-life calculated from the above parameters. Finally, the coefficient of variability is, if anything, larger in the morphine series (Table II) than in the papaveretum group that involved a wider selection of operative sites. All this suggests that valid comparisons may be made between the two groups.

The average morphine loading dose of $0.33 \mathrm{mg} / \mathrm{kg}$ will come as a surprise to many readers of the American literature. ${ }^{8-10}$ In fact, this figure may be reduced 25 per cent further by using promethazine for premedication ${ }^{6}$ or by about 18 per cent if morphine is administered in the form of papaveretum (Table II, Figure 1). It is a tribute to the precision of time/dose curve analysis that in a combined series of 78 subjects, the differences in all parameters reached statistical significance of 
some degree. Much larger differences in narcotic potency are usually necessary before they can be documented by clinicians.

There is clear inference from the data in Table II that codeine, papaverine and thebaine contribute approximately 18 per cent of the anaesthetic action of papaveretum. Since these drugs have shorter half-lives than morphine, one would expect that increments of the maintenance dose would have to be administered at closer intervals; in other words, the therapeutic half-life of papaveretum would be shorter (or its therapeutic rate constant larger) than that of morphine. Figure 1 bears out this assumption. It is also possible to perform some semi-quantitative calculations and to check the data presented in Table II. If, as is shown, the secondary alkaloids in papaveretum contribute the equivalent of $0.059 \mathrm{mg}$ of morphine sulphate per $\mathrm{kg}$ and if the biophase half-life of these substances is 2 hours (a valid assumption for codeine) then the amount of morphine sulphate per $\mathrm{kg}$ per hour needed to replace it as it is inactivated $(X)$ is, according to the law of first-order kinetics:

$$
\begin{aligned}
\mathrm{X} & =0.059 \times 0.692 / 2 \\
& =0.0204 \mathrm{mg} / \mathrm{kg} / \mathrm{hr} .
\end{aligned}
$$

This amount must be subtracted from the observed maintenance rate of morphine in papaveretum $(0.0495 \mathrm{mg} / \mathrm{kg} / \mathrm{hr})$ to yield the true morphine maintenance rate of $0.0291 \mathrm{mg} / \mathrm{kg} / \mathrm{hr}$. Dividing the latter by the loading dose.

$$
0.0291 / 0.271=0.1074 \mathrm{hr}^{-1}
$$

one obtains the true therapeutic elimination rate constant of morphine in the papaveretum series. This is in excellent agreement $(t / 2=6.44 \mathrm{hr})$ with the mean therapeutic rate constant obtained in the morphine series $\left(0.1120 \mathrm{hr}^{-1}, \mathrm{t} / 2=6.18\right.$ $\mathrm{hr})$. Thus an 18 per cent contribution to the activity of morphine in papaveretum by shorter-acting alkaloids nearly halves the therapeutic half-life of that compound ( 42 per cent reduction) compared with morphine.

Although a mean inactivation rate of $0.19 \mathrm{hr}^{-1}$ is still less than ideal $\left(0.25 \mathrm{hr}^{-1}\right.$ appears to be the most desirable for the operating room) it is clearly superior to the $0.11 \mathrm{hr}^{-1}$ of morphine and may represent a useful compromise between peroperative and post-operative drug requirements. Careful anaesthetists can handle long-acting narcotics in the operating room just as successfully as short-acting ones. Problems might occur at the end of the operation, however, when the patient is exposed to a sudden reduction of sensory input as dressings are applied and he is transferred from the operating table to a bed in the recovery area. If this process is not matched by an equally sharp drop-off of anaesthetic agents in the central nervous system, transitory but potentially dangerous respiratory depression may set in. While narcotic antagonists and short-term respirator treatment will resolve such an emergency, the ideal approach remains to select the drug that will provide the desired depth of anaesthesia during the operation and the right degree of residual analgesia for the desired length of time after administration has been stopped. For anaesthetists who like to use morphine, papaveretum will provide a useful addition.

\section{SUMMARY}

Intravenous papaveretum was used for the induction and supplementation of nitrous oxide-relaxant anaesthesia in 32 subjects undergoing major surgical oper- 
ations. An anaesthetic time/dose curve was constructed from the size and timing of successive narcotic increments received by each patient and from these the loading and maintenance requirements of the group were determined. Compared with a similar series in which plain morphine was employed in the same fashion, the morphine content of papaveretum accounted for only 82 per cent of the observed anaesthetic activity. Since the remaining 18 per cent was provided by more readily inactivated alkaloids, papaveretum's therapeutic half-life was only 58 per cent $(3.61 \mathrm{hr})$ of morphine $(6.18 \mathrm{hr})$. All the statements outlined above proved to be statistically significant to various degrees. The advantages of a shorter acting morphine-like compound in anaesthesia are discussed.

\section{RÉsumé}

Le papaveretum (mélange des quatre principaux alcaloïdes de l'opium: morphine, papavérine, codéine et thébaïne) fut utilisé comme agent d'induction et comme supplément à une anesthésie au protoxyde-curare, ceci chez trente-deux malades soumis à une intervention chirurgicale majeure. Une courbe anesthésique dosedurée sur la base des doses initiales et de l'intervalle entre les doses additionnelles reçues par chaque patient, a été établie. A partir de cette courbe, la dose moyenne d'induction et les taux moyennes de maintien ont été établies.

Comparée à une série contrôle, où l'on utilisait la morphine de la même façon, l'activité anesthésique observée était due dans une proportion de 82 pour cent au contenu en morphine du papaveretum. Le 18 pour cent restant étant fourni par des alcaloïdes plus facilement inactivés, la demi-vie du papaveretum était plus courte que celle de la morphine ( 3.61 heures vs 6.18 ).

Tous les résultats obtenus étaient significatifs à divers degrés. Les avantages d'un morphinomimétique d'action plus court que la morphine sont discutés.

\section{REFERENCES}

1. Keeri-Szanto, M., Telmosse, F., \& Trop, D. Anaesthetic time/dose curves V. Data on neuroleptic drugs with remarks about their action. C.A.S.J. 10: 484-490 (1963).

2. Beaulieu, Danielle, Goyette, M., \& Keeru-Szanto, M. Anaesthetic time/dose curves VI. Experiences with diazepam. C.A.S.J. 14: 326-332 (1967).

3. Gerula, G.R. \& Keeri-Szanto, M. Anaesthetic time/dose curves VII. Experience with pentazocine. C.A.S.J. 18: 84-91 (1971).

4. KeEri-Szanto, M. Isokapnic ventilation: description of equipment and first results. Anaesth. Analg. 49: 406-412 (1970).

5. Keeri-Szanto, M. Drug consumption during Thiopentone-nitrous oxide-relaxant anaesthesia: the preparation and interpretation of time/dose curves. Brit. J. Anaesth. 32: 415$423(1960)$.

6. Keeni-Szanto, M. Promethazine's mode of action in potentiating narcotic drugs. Brit. J. Anaesth. 46: 918-924 (1974).

7. Loan, W.B., Dundee, J.W., \& Clarke, R.S.J. Studies of drugs given before anaesthesia: XII comparison of papaveretum and morphine. Brit. J. Anaesth. 38: 891-900 (1966).

8. Romagnoli, A. The relative potencies of fentanyl and morphine. Anesthesiology 39:568570 (1973).

9. Keeri-Szanto, M. Potencies of fentanyl and morphine. Anesthesiology 40: 518-519 (1974).

10. Lappas, Demetrios G., et al. Filling pressure of the heart and pulmonary circulation of the patient with coronary-artery disease after large intravenous doses of morphine. Anaesthesiology 42:153-159 (1975). 